JEAL JOALL (JOURNAL OF APPLIED LINGUISTICS AND LITERATURE)

Vol. 7 No. 1, February 2022

ISSN (print): 2502-7816; ISSN (online): 2503-524X

Available online at https:/ / ejournal.unib.ac.id/index.php/joall/article/view/18724

http://doi.org/10.33369/joall.v7i1.18724

\title{
Improving EFL ninth graders' reading comprehension through thieves learning strategy
}

\author{
1Yenny Asmarni ${ }^{(D)}$, 2Wisma Yunita ${ }^{(D)}$, 3Dedi Sofyan \\ 1SMP Negeri 13 Bengkulu Utara, INDONESIA \\ 1Jalan Raya Pasar Ketahun, Bengkulu Utara 38361
}

2,3Postgraduate Program of English Education, Faculty of Teacher Training and

Education, University of Bengkulu, INDONESIA

${ }^{1}$ Jalan W.R. Supratman, Kandang Limun, Bengkulu 38371

\begin{tabular}{l}
\hline \hline ARTICLE INFO \\
\hline \hline Article history: \\
Received: Oct 30, 2021 \\
Revised: Feb 09, 2022 \\
Accepted: Feb 21, 2022 \\
\hline Keywords: \\
THIEVES Strategy \\
EFL Students' Reading \\
Comprehension Skills \\
Classroom Action Research \\
\hline Conflict of interest: \\
None \\
\hline Funding information: \\
None
\end{tabular}

Correspondence

Yenny Asmarni, SMP Negeri 13

Bengkulu Utara, INDONESIA.

yennydaman1@gmail.com

\begin{abstract}
Reading as a fundamental language skill become an essential skill in academic and social life. Especially at school, the teachers need to enrich the strategy in teaching and learning process. The objectives of this study were to find out 1) the improvement of students' reading comprehension of the ninth grade (IXC) of SMPN 13 North Bengkulu, 2) some factors influence the change of students' reading comprehension at the ninth grade (IX C) of SMPN 13 North Bengkulu. This Classroom Action Research (CAR) involved 25 students of the ninth grade of SMPN 13 North Bengkulu. Quantitative and qualitative data were employed to investigate the improvement of the students' reading comprehension and the factors influence the changes of students' reading comprehension. Reading comprehension test, observation checklists and field notes, and interview were the instruments of this research. Based on the test results, the percentage of students who had achieved the success criteria increased from $8 \%$ at the baseline to $80 \%$ at the end of the study. It can be concluded that applying Thieves strategy improved students' reading comprehension and it was influenced by the student's factors (attention, interest and participation) and the teacher's factors (enriching the material and classroom management).
\end{abstract}

Asmarni, Y., Yunita, W., Sofyan, D. (2022). Improving EFL ninth graders' reading comprehension through thieves learning strategy JOALL (Journal of Applied Linguistics and Literature), 7(1), 232-258. https:// doi.org/10.33369/joall.v7i1.18724

Doubtlessly, reading as a fundamental language skill become an essential skill in academic and social life. By reading, someone can reach some good things in his/her social life and academic. Nunan (2015) defines reading 
as a process of making some symbols to be pronounced as a sound. While, Anderson (2012) states that an enthusiastic and productive reader in the twenty first century can be an academically successful individual. Indeed, reading and listening are characterized as receptive skills. The absolute differences between them are when someone listened to the words it will immediately lose to the air after it has been spoken. However, reading exists as permanent words that can be revisited to be read.

Furthermore, the main purpose of reading is comprehension. Ediger, (2001) argues that the purpose of reading comprehends the text. Özdemir \& Akyol (2019) assert its matter in lifelong learning, reading comprehension has an important place and there is an interactive process between the reader and the text. It means that reading comprehension is needed to be mastered by the students at all educational levels and the entire school subjects.

In Indonesia, reading is examined at the National Level in the National-based School Exam (USBN) and Computer Based National Examination (UNBK). In the exam, there are some questions provided to assess the students' reading comprehension. Moreover, students' reading comprehension is still problematic. In 2018/2019 Academic year, in Computer Based National Examination, the average of English subject reached 49,56 in National Level while in North Bengkulu it was 43,45. It revealed that the result of Computer Based National Examination in North Bengkulu was lower than the result of National level.

Considering to the condition at SMPN 13 North Bengkulu, the students' reading comprehension proficiency especially for grade nine is still low. Grade nine is divided into three classrooms, class IX A, IX B, and IX C. In the last semester, there were 8 out of 20 students ( $40 \%)$ obtained D in class IX A, and there were 9 out of 23 students (39\%) obtained D in class IX B, while 14 out of 25 students (56\%) obtained D in class IX C. It is proven by the baseline data that class IX C obtained the highest percentage of D category. The specific data will be described as follow; 14 out of 25 students (56\%) obtained under 70 or D category, 9 out of 25 students $(36 \%)$ obtained $70-80$ or C category, and 2 out of 25 students $(8 \%)$ obtained 83 and 87 or B category. None of them obtain more than 90 or A category. The Minimum Standard Score (KKM) at the school is 70 or C. In addition, by a little observation done by I, the students' attitude and motivation in learning reading was still low.

In learning process, learning strategy become an educational activity carried out by teachers and students so that learning objectives can be achieved effectively and efficiently. As Sofyan (2016) revealed students' reading comprehension can be affected by learning strategy, thus, the teacher should adjust the students' learning style in determining the learning strategy for the students. 
Based on the data above, the students are not proficient in reading comprehension. Consequently, some strategies should be found to overcome the issue. There are various strategies, such as SCRATCH, PBL, INSERT and SQ3R which can be used to enhance the students' reading comprehension abilities. Papatga \& Ersoy (2016) found that the reading level of the participants of the research who had problems in reading comprehension arose from the apprehension level to the educational level in some forms and even to the independent reading level in other forms. In other words, there was an enhancement in the reading comprehension skills of all the participants by using the SCRATCH program. Next, Lin (2017) concluded that the participants of reading comprehension in English classes of Taiwanese University improved significantly by using the Problem Based Learning (PBL) approach. The PBL participants used the strategy to identify the subject matter and supportive details which better than their counterparts. Additionally, Gurning \& Siregar (2017) showed that after applying the INSERT strategy, the students' reading comprehension achievement was higher than using the SQ3R strategy.

Among all those strategies, THIEVES strategy becomes one of the interesting strategies to be applied. Manz (2002) claims that the steps of THIEVES strategy are arranged to urge the metacognitive processing. There are some researchers who have examined THIEVES strategy. The first researcher Khataee (2019) who claimed that applying the THIEVES strategy can enhance the comprehension of expository texts. Meanwhile, the second researcher Novia (2013) who revealed that the reading skill of eight - grade students of SMP Negeri 2 Teluk Gelam can be improved significantly by using THIEVES strategy. The third researcher, Sarifuddin and Nunggrasari (2019) concluded that the use of THIEVES strategy discovering a significant effectiveness toward students' motivation in reading comprehension.

Based on the description above, through some steps of the strategy which are arranged to urge the metacognitive processing, THIEVES strategy become the most appropriate strategy to be applied in order to improve students' reading comprehension. The students' low proficient in reading comprehension test and their low motivation in reading comprehension become hardest problem to be solved. Therefore, the objective of this research is to find out the students' reading comprehension improvement and some factors influence the change of students reading comprehension by applying THIEVES strategy.

One of the four English skills that should be mastered by the students is reading. It is the process of making some symbols to be pronounced as a sound, and have meaning (Nunan, 2015). While Sheng (2000) explains that Reading is the process of recognizing, interpreting, and perceiving written or printed materials. It can be concluded that reading is a process of making 
several symbols to be pronounced as a sound, recognition, interpretation, and perception of written or printed material.

In addition, Grabe and Stoller (2013) conclude that reading is the ability to describe the meaning and clarify the information in the text correctly. On the other hand, Moreillon (2007) assumes that drawing the meaning of the printed and unprinted text is not simple, but need a high practice and ability in an active process. It can be said that reading is complex and not easy to do. By reading, there will be a process of acquiring. They will be easier to get their need by reading. Thus, the students may need to read. McDonough, J., Shaw, (2013) explain the reasons as follow:

1. To get information to reach the goal or aim or the topic are interesting for the students.

2. To get some pointers on how to do some tasks for our work and daily life.

3. To stay close with friends by sending some messages or business letters.

4. To recognize whether something will take place and available.

5. To recognize the hot issues happening in newspaper, magazines, and reports.

6. To have entertainment and eagerness.

While Grabe and Stoller (2013) explain the purposes of reading as the following sentences:

1. Searching for the simple information by reading and reading to skim.

2. Learning from text by reading that occurring in academic and social context.

3. Integrating information by reading sometimes need the critical evaluation of the information in order to integrate the purpose of the readers.

4. Searching for the information which needed for someone's writing by reading.

5. Giving some critique texts by reading.

6. Getting general comprehension by reading

Based on the explanations above I concludes that beside as an important thing for a human being, reading is a process of not only pronouncing some written or printed but also the way how to get the meaning of the written and printed symbols.

There are some definitions of reading comprehension. Snow (2002) states that reading comprehension is the process of extracting and constructing meaning at the same time through interaction and engagement with written language. This process will not occur unless the teacher can identify and address the problems that cause students' reading comprehension difficulties. While, Tindall, E., and Nisbet, (2010) call reading 
comprehension as "the focus of all reading engagements" because readers must be able to read texts fluently, have adequate knowledge and vocabulary, and be able to put in strategies while reading. Ediger (2001) argues the objective of reading is to comprehend the text. Özdemir and Akyol (2019) conclude that in lifelong learning, reading comprehension has an important position and there is an interactive process between the reader and the text. It means that reading comprehension is needed to be mastered by the students at all educational levels and for all school subjects. However, Klingner, J.K., Sharon, V. \& Alison, (2007) state that reading comprehension is a very complicated process that contains many components and involves a lot of interaction between the reader and the text he is reading.

There are five basic comprehension processes which work and complement one another simultaneously as mentioned by Irwin in Klinger, Vaughn, and Boardman (2007) below:

1. Micro processes, it means the readers begin by grouping words into phrases or groups that have meaning and require understanding of syntax and vocabulary.

2. Integrative Processes refer to the process of understanding and concluding the relationships among clauses.

3. Macro processes is the process of summarizing the main ideas from the text that has been read or in other words selecting the most important information and eliminating the less important information.

4. Elaborative processes refer to making use of prior knowledge and, drawing conclusions beyond the points described explicitly in the text.

5. Metacognitive processes refer to those involved in controlling understanding, choosing what to remember, and adjusting the strategies used when reading.

In conclusion, the basic comprehension processes are related all together. The process is begun by micro processes, integrative process, macro process, elaborative processes and metacognitive processes. Thus, I arranged the grid of reading comprehension test which consisted of basic competence, indicators of competence achievement, subject matter, indicator of the items, form of the items, and number of the items.

Meanwhile, Thieves was suggested by Suzanne Manz. In this strategy, Manz (2002) defines that THIEVES is an activating strategy that has seven steps and aims to provide students with the necessary knowledge before going through the text. The strategy helps students to activate their previous knowledge (schemata are broad concepts which are store in our memory, (Kibui, 2017). THIEVES is an early reading strategy that students can use to "steal" information from titles, headings, introductions, first sentences, 
visuals/vocabulary, endings and summaries. THIEVES strategy approaches to previewing text in depth and develops to help the students activate their background knowledge and predicting the content that they will be encountering while reading. Compared to the other strategies, Thieves strategy can be used in every kind of text (text type).

Manz (2002) proposes the steps of THIEVES and can be described as follow:

1. Title: In this step the students have to find information about this topic, the relationship between this topic and the chapter, the title present point of view, and the text's message.

2. Headings: In this step the students have to find out the paragraph beneath this heading about, information this heading tells the students, change this heading into a question to be answered in the text, and the students can understand from this heading.

3. Introduction: In this step the students have to find out information in the first paragraph provide about the whole chapter, knowing whether the first paragraph introduce the chapter well, whether this introduction provides the reader about what she/he will read, and whether the readers have any knowledge about this topic.

4. Every first sentence in a paragraph: In this step the students have to find out whether the whole chapter provide something according to the first sentence in each paragraph.

6. Visuals and vocabulary: In this step the students have to find out the way to interpret information through the photographs, drawings, maps, charts, or graphs in the chapter, a complete list of key vocabularies and definitions of the chapter, the important words of the chapter in boldface type throughout the chapter, and the students can understand the meaning in the boldface.

7. End-of-chapter questions: In this step the students have to find out the questions want, information the students need to answer the questions, information the students can learn from the questions, the students should keep in mind the questions at the end of the chapter, so the students can find where the information is located.

8. Summary: In this step the students have to find out the summary about the topic.

Based on the explanation above, it can be concluded that Thieves help reader to identify important concept, and establish a context for reading. So, after introducing the strategy, the students can read the text at the same time frame, or they can do THIEVES ahead of time to prepare to read for homework or the next day. After reading, the students refer back to their THIEVES graphic organizer to consider what they accurately predicted, what they missed, and what questions they can now answer. 


\section{METHOD}

\section{Design}

This research is a Classroom Action Research (CAR). Hopkins (2004) states that action research is a type of research in which teachers look critically at their own classrooms and use the research for developing their teaching skills and qualities in their schools. Some actions are combined to collect the data.

In addition, Phillips, D.A. \& Carr (2010) define that Classroom Action Research (CAR) is part of various types of classroom action research from several other themes such as participatory research, critical action research, and action learning. Additionally, Gay, L. R. and Peter (2000) explain action research as a type of professional research that is used to advance the professional practice which the action implies doing or changing something. Then, it can be concluded that action research is focused in developing the classroom teaching and learning to be better. I did the study with the other English teacher as a collaborator. Then, the research conducted for cycles. Optimistically, it can enhance the students' ability especially in reading comprehension.

\section{Instruments}

Some instruments were needed to bring out different kinds of data. I was the key of the instrument. I engaged reading comprehension test, observation checklist, field notes, and interview which were important to diagnose problems in the classroom in detail and also to advance the students' reading comprehension skill.

\section{Reading comprehension test}

At the end of each cycle, the test was allocated individually. I gave a narrative and a report reading comprehension test to the students based on the indicators of this research. There were 20 items of multiple choices. This test was guided by a worksheet which contained a table of some indicators. The distractors consist of four choices, because of the students are in the Junior High School level.

\section{Observation checklists and field notes}

The observation checklist and field notes accommodated the indicators and sub indicators which were made based on the activities of the strategy. They were utilized during the teaching and learning process. The collaborator assisted me to observe and collect the information during the teaching and learning process by filling the observation checklist and the field notes. The Guttman scale was adopted as the scale type, likely "Yes and No" form. 


\section{Interview guided questions}

This instrument was utilized as a way to gain data related to the students' activities in learning and practicing reading comprehension by using THIEVES strategy. An interview was used in order to know the students' feelings and attitude towards the teaching learning process. The guided of the interview was taken from the indicators. The interview section was done after the class is over.

\section{Data collection procedure}

The data collection procedure adapted the theory proposed by Kemmis. The data was taken from the students' reading comprehension test result, observation checklist and fieldnotes, and interview. Those procedures were conducted as long as the cycles and after the cycles be done. Firstly, reading comprehension test was done after each cycle. While, the observation checklist and field notes were taken when the cycle was occurring. Finally, the interview was done after conducting cycle I and cycle II.

\section{Data analysis technique}

The data of this study can be divided into two forms, as for quantitative data and qualitative data. Quantitative data was obtained from the students' reading comprehension test. Qualitative data was gathered from observation checklist, field notes, and interview.

\section{Quantitative data}

There were various techniques to analyze the quantitative data of reading comprehension test. After applying the strategy, I gave the test at the end of the cycle to get the result. The score of students' reading comprehension test was calculated by using the formula below.

Note: $S=$ The students' score

$$
S=\frac{X}{Y} \times 100
$$

$X=$ The total number of the correct items

$Y=$ The total number of the reading test items (Sudijono, 2006)

After the students' score were obtained, the students' score needs to be classified by using the percentage in order to find the criteria of success. The formula to count the percentage could be seen as follows.

Note: $\mathrm{P}=$ percentage number

$$
P=\frac{f}{n} \times 100
$$

$\mathrm{f}=$ number of students (pass the standard score)

$\mathrm{n}=$ total number of the students (Sudijono, 2006) 
The score of students' reading comprehension score above were used to grade students' reading comprehension in each cycle. Research was considered to be successful if $70 \%$ of the total number of students reaches $>80$.

Table 1. The Predicate and Category of the Students Achievement

\begin{tabular}{lll}
\hline Value interval & Predicate & Category \\
\hline $91-100$ & A & Very Good \\
$81-90$ & B & Good \\
$\geq 70-80$ & C & Fair \\
$<70$ & D & Poor \\
\hline & (Adapted from Panduan Penilai Pendidik SMP 2016)
\end{tabular}

\section{Qualitative data}

After the process of classifying, the data were displayed in the chart form. The data represented the classification of its level in each cycle. Next, it was chance to make the qualitative analysis. In the process of qualitative analysis, I adopted the technique proposed by Gay, L. R. and Peter (2000).

After the observation checklist and field notes data had gathered, the data should be listed according to its type. In this first step of data analysis, I resumed the observation and analyzed the result. Then, I made some notes. In the next step, I described the data that have been collected and read. Last step, the data should be interpreted. I interpreted the research findings in written or description form. Thus, these findings were explained more detail in qualitative data.

\section{Criteria of success}

The following are the criteria for the success of a classroom action research. They are:

1. The THIEVES strategy could improve students' reading comprehension with $70 \%$ of all total students achieving B grades (81 90) based on the Minimum Standard Value.

2. The students' motivation increased as indicated by their interest, actively involved in class activities, in pairs and individually during the implementation of the THIEVES strategy as evidenced by observation checklists, field notes, and student interviews.

\section{FINDINGS}

At the cycle I, based on the result of the students' reading comprehension test, observation checklist and field notes, I found that some students were still confused on how to use the steps of the strategy. They sat in their groups and asked the teacher about this step. When the teacher found more than two students asked the same question in this step, the teacher gave them the explanation in detail. Thus, the students knew what they needed to do. On 
the other side, some students just talked to each other without paying attention to the teacher's explanation. Lastly, the teacher could manage it well.

In cycle II, I did some revisions so that those could build the students' enthusiasm in the teaching and learning process than in cycle I. I provided more attention and responded to the students in building their enthusiasm during the teaching and learning process.

The entire action research process, the quantitative and qualitative data, which discovered the students' reading comprehension scores and developmental level before and also after the implementation, was collected altogether. The findings were displayed in this section.

It can be seen that the students' reading comprehension skills improve after applying the THIEVES strategy. It can be proven by the result of students' reading comprehension test in cycle I and II. The improvement could be identified as significant improvement. The data was displayed within chart which can be uncovered as follow

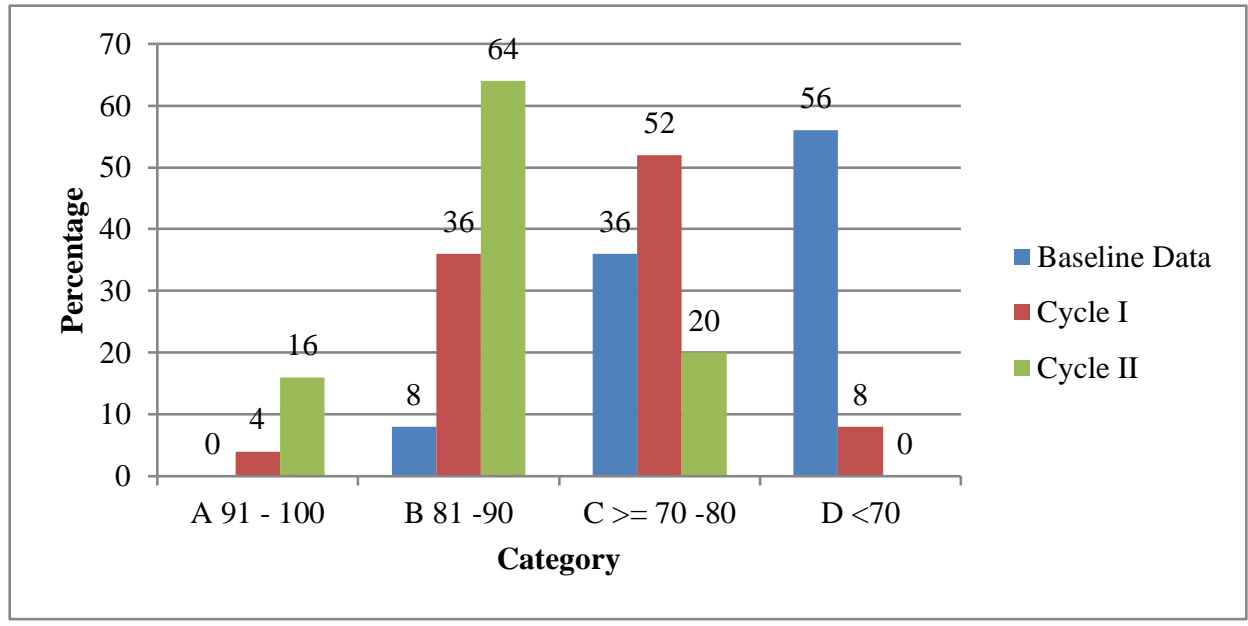

Chart 1. The improvement of students' reading comprehension test in baseline data and cycle I to cycle II.

From the chart above, it can be clarified that there was an improvement in each cycle. From the beginning (baseline) data to the cycle I, there was an improvement score. The students in the A category had improved from 0 out of 25 students in baseline data to 1 of 25 students (4\%) in cycle I. Meanwhile, the students in B category improved from 2 out of 25 students $(8 \%)$ in baseline data to 9 out of 25 students (36\%) in cycle I. Thus, the students who had reached the criteria of success increased from only 2 out of 25 students $(8 \%)$ in baseline data became 10 out of 25 students (40\%) in cycle I.

In addition, there was also an improvement from cycle I to cycle II. The percentage of the students in A category improved from 1 out of 25 students $(4 \%)$ in cycle I to 4 out of 25 students $(16 \%)$ in cycle II. The percentage of the 
students in B category improved from 9 out of 25 students (36\%) in cycle I to 16 out of 25 students (64\%) in cycle II. Hence, the students who had achieved the success criteria improved from 10 of 25 students (40\%) in cycle I became 20 of 25 students $(80 \%)$ in cycle II. As the consequences, the result of the reading comprehension test was improved from cycle I to cycle II after the process of applying the THIEVES strategy to the ninth-grade students in SMPN 13 North Bengkulu.

Moreover, I also perceived there was the improvement of the students' reading comprehension from the result of the students' observation checklist and field notes in cycle I and cycle II. There was a significant improvement of students' understanding in applying Thieves strategy. The improvement of students' understanding in applying Thieves strategy will be described by the chart below;

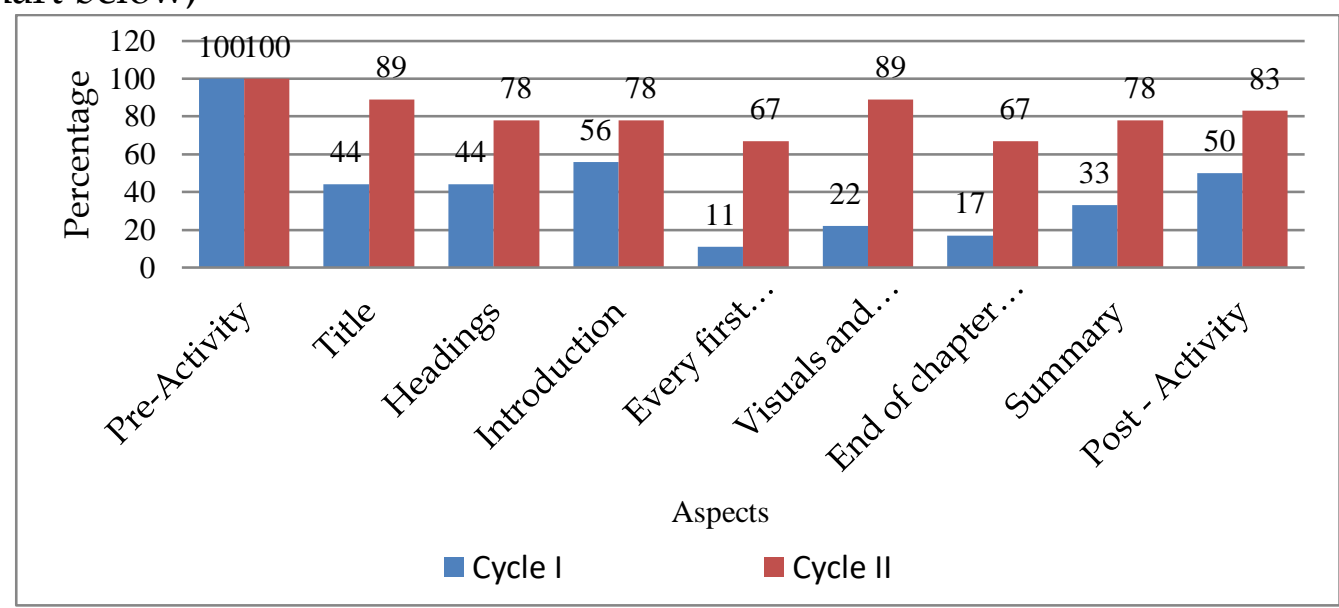

Chart 2. Recapitulation of the Observation Checklist of Cycle I and Cycle II

\section{Table 2. Field Notes for Teacher and students}

\begin{tabular}{cl}
\hline No & Fycle \\
\hline 1 & In the first meeting, the teacher began the learning \\
process and managed the classroom well. She just told \\
about main idea without asking the information the \\
students had got from the text. She had given the \\
explanation about each step but the students were still \\
very confusing about the steps of the strategy. There still \\
some students who did chatting among the students \\
which were in the different group. At the end of the \\
meeting she tried to summarize what the students got at \\
this meeting then closed the meeting well. At the second \\
meeting, the teacher began the meeting well. She \\
managed the classroom well and effective. She gave the \\
explanation about the strategy, step by step, little by little. \\
So that the students were not so confused about the \\
strategy and start to be more enthusiasm in doing their \\
task. Finally, the teacher closed the meeting very well. In
\end{tabular}




\begin{tabular}{ll}
\hline No & \multicolumn{1}{c}{ Field notes } \\
\hline & the third meeting, the teacher had given the explanation \\
clearly. Almost all steps were done well by the teacher \\
In the first meeting of cycle II, the teacher began the \\
learning process very well. She gave the explanation \\
about THIEVES strategy and what the students should \\
do in this meeting clearly. The students had understood \\
enough about the steps of THIEVES strategy. Only two \\
or three students who asked about the steps. They still \\
found some difficulties in step Every first paragraph. \\
Then, in the second meeting after opening the class and \\
giving the explanation about what should the students \\
do, the teacher come to each group to ask whether they \\
found some difficulties in applying THIEVES strategy to \\
comprehend the text they had. The students showed a \\
very good respond. They looked very happy and \\
enthusiasm to do their task by applying the strategy.
\end{tabular}

Based on Chart 2, it can be seen that students' understanding in implementing each step of Thieves strategy increased significantly from Cycle I to Cycle II. The chart shows that step 1 (Title) (44\%), step 2 (Title) (44\%), and step 3 (Introduction) have a higher percentage compared to step 4 (Each first paragraph) (11\%), step 5 (Visual and Vocabulary) (22\%), step 6 (Chapter end questions) (17\%), and step 7 (Summary) (33\%) in cycle I. However, the three initial steps were factors that improved students' reading comprehension.

In the second cycle, each steps showed an improvement. The chart above exhibited that the fourth, fifth, sixth, and seventh steps illustrate that the students became more active. The percentage increased from $11 \%$ to $67 \%$ for the fourth step, $22 \%$ to $89 \%$ for the fifth step, $17 \%$ to $67 \%$ for the sixth step, and $33 \%$ to $78 \%$ for the seventh step.

In the second cycle, each step shows its improvement. The chart above shows that the fourth, fifth, sixth, and seventh step described the better improvement of the activeness of the students. The percentage improved from $11 \%$ to $67 \%$ for the fourth step, $22 \%$ to $89 \%$ for the fifth step, $17 \%$ to $67 \%$ for the sixth step, and $33 \%$ to $78 \%$ for the seventh step.

Doubtlessly, the students' observation checklist and field notes indicated the better improvement of students' activeness in every cycle during the teaching and learning process. In the first cycle, step one (predicting what the chapter will be discussed from the title), step two (predicting the information based on the heading), and step three (predicting the introduction) tend to be easier to be applied. It was proven by the chart (see chart 2) and field notes (see table 2). It was not only the students' activeness but also teacher's participation became the most important factors in improving the students' reading comprehension. 
There were also some interviews that have been done by I after doing the cycle I and cycle II. The result of the interviews revealed that applying the THIEVES strategy could stimulate the students to be more active in the teaching and learning process. A part of the answer conducted with respondent at the middle of the implementation process is given below.

"kalo sebelumnya, waktu liat teks, apalagi kalo teksnya panjang. saya langsung putus asa aja, Mam. Dan kurang semangat mau tau tentang teksnya. Tapi, pas dikenalin strategy ini jadi penasaran pengen tau dan semangat buat tau dengan menerapkan urutan dalam strategynya. Mulai dari judulny sampai menyimpulkan isi teksnya. Dari strategy ini saya dapat mempredeksi pertanyaan apa yang akan muncul dari teks dan jawabannya." (Previously, when I saw the text, especially if the text was long. I just gave up, Mam. And not excited to know about the text. However, when I was introduced to this strategy, I was curious to know and excited to know by applying the order in the strategy. Starting from the title to concluding the content of the text. From this strategy I can predict what questions will arise from the text and the answers)

From the data above, it can be assumed that the students were confused with the English text. Moreover, concerned to the complex text, the student was not eager to know more about the text. However, when the student was introduced to the THIEVES strategy, the students were curious and enthusiasm to know and apply the strategy. It was started from the title to summarization section. By applying this strategy, the student could predict what kind of questions that will be appeared from the text.

\section{DISCUSSION}

Considering to the result of students' reading comprehension test, it showed that there was a significant improvement of the students' reading comprehension in each cycle. In cycle I, there was an improvement compared to the baseline data. Unfortunately, students' achievement did not reach the criteria of success. In cycle I, the THIEVES strategy was just introduced to them. At the first and second meeting, the students were still confused about the strategy, especially at the step 4 (Every first paragraph sentence), step 5 (Visuals and vocabulary), step 6 (End of chapter question), and step 7 (Summary). While, in step 1 (Title), step 2 (Heading) and step 3 (Introduction) they tend to be easier in understanding the steps. They could immediately predict what they have seen from the title, heading and introduction. Because of the reading comprehension test result did not reach the criteria of success, I needed to implement the second cycle, there was also an improvement compared to reading comprehension test result in cycle I. Then, at the end of cycle II, I found that the improvement of students' reading comprehension 
result has reached the criteria of success. Finally, I stopped in cycle II. The percentage of students who got B and A category has reached the criteria of success. This finding showed that after applying the Thieves strategy, the students' reading comprehension were improved and reached the criteria of success.

Furthermore, according to the teacher's observation checklists and the teacher's effort, those also affected the teaching and learning process. The teacher's participation has a crucial role in introducing the materials. There was not only their attendance among the students but also the preparation, explanation, instruction, feedback and also rewards for the students. Then, I concluded that the appropriate strategy for the suitable learning objective, media, and the teacher's action become the factors of the improvement of students' reading comprehension skills.

The findings of this study were similar to some previous studies established by the other researchers. Khataee (2019) claims that applying the THIEVES strategy can enhance the comprehension of expository text. Furthermore, a study by Novia (2013) proved that the reading comprehension of students who were taught using the THIEVES strategy was better than students who were. However, the THIEVES strategy can improve the reading ability of eighth grade students of SMP Negeri 2 Teluk Gelam. In addition, the research of Sarifuddin and Nunggrasari (2019) also found that Thieves' strategy was more effective in increasing students' motivation in reading comprehension.

The THIEVES strategy activated the students through some steps that were applied to improve the students' reading comprehension skills. Similar to the theory by Manz (2002) who defines that THIEVES is an activation strategy involving seven steps which aims to provide the necessary knowledge for students before studying the text deeper. Each step of the strategy enabled the students to get every single information in the text.

Based on the reflection of the first cycle, I did some improvements to overcome students' confusion through first cycle. The good respond was given by the students in the teaching and learning process because the new strategy was combined by enriching the lesson of the material. The distribution of materials to the students in cycle II was more various than cycle I.

In sequence, in order to improve students' enthusiasm and attraction in cycle 2, I combined and enriched the several text which were taken from some resources. By combining and enriching the various kind of texts, the students became more active and paid more attention to the teaching and learning process. It showed that the participation of the teacher also become a factor which affects the students' enthusiasm in the teaching and learning process. As Sari et al. (2018) revealed that teacher's participation in combining and 
enriching the various kinds of texts reinforced the teaching and learning process. Hence, it made the students to be more attracted and attentive into materials.

Finally, from the discussion above, it can be concluded that the application of the THIEVES strategy through several cycles is effective in improving students' reading comprehension and strengthening the teaching and learning process. The students became more active and interested when the teacher applying this strategy to teach reading. In addition, the THIEVES strategy was an appropriate strategy to be applied for various types of texts.

\section{CONCLUSION}

Based on the discussion above, some conclusions can be drawn. First of all, students' reading comprehension test has reached the criteria of success. It was proven by the students' reading comprehension test result in cycle I and cycle II. The students who have reached the criteria of success upgraded from 2 students in baseline data became 20 students in the end of the study. Second, the observation checklist and field notes confessed the students' activeness during the process of teaching and learning. The teacher's creativity in elaborating several kinds of text has assisted the students to be more curious to the materials. In addition, the students became more active and concentrated. They also could expose their ideas and scheme on their mind during the discussion section was implemented. In brief, it was uncovered that all of the students' reading comprehension strategies called the THIEVES strategy. Based on this discussion, it can be declared that this strategy can be used in reading comprehension activities at junior high school level.

\section{ACKNOWLEDGMENTS}

This research was supported by The Faculty of Teacher Training and Education, The Department of Language and Art, English Education Postgraduate Program. We thank Mr. Azhar Aziz Lubis as the editor of JOALL and anonymous reviewers for their helpful comments and suggestions. We would also like to show our gratitude to the school principles of SMPN 13 North Bengkulu Syuraiani, S.Pd., M.Pd. for sharing her pearls of wisdom with us during the course of this research.

\section{REFERENCES}

Anderson, N. J. (2012). Reading Instructions.pdf. Cambridge University Press. Ediger, A. (2001). eaching children literacy skills in a second language. Thomson Learning, Inc.

https:/ / scholar.google.com/scholar?hl=en\&as_sdt=0\%2C5\&q=+IEdige r \%2C+A.+\% 282001\%29.+Teaching+children+literacy+skills+in+a+secon $\mathrm{d}+$ language\&btnG $=$ 
Gay, L. R. and Peter, A. (2000). Educational Research: Competencies for Analysis and Application (6th Ed). Prentice Hall, Inc.

Grabe, W., \& Stoller, F. L. (2013). Teaching and researching reading, second edition. In Teaching and Researching Reading, Second Edition. https://doi.org/10.4324/9781315833743

Gurning, B., \& Siregar, A. (2017). The Effect of Teaching Strategies and Curiosity on Students' Achievement in Reading Comprehension. English Language Teaching, 10(11), 191. https://doi.org/10.5539/elt.v10n11p191

Hopkins, D. (2004). Action Research and Classroom research by teachers. $A$ Teacher's Guide to Classroom Research, 47-58.

Khataee, E. (2019). The effect of THIEVES strategy on EFL learners' reading comprehension. International Journal of Instruction, 12(2), 667-682. https://doi.org/10.29333/iji.2019.12242a

Kibui, A. W. (2017). Pedagogical Implication of Schemata In Reading Comprehension in the English Language. 5(4), 89-94.

Klingner, J.K., Sharon, V. \& Alison, B. (2007). eaching Reading Comprehension to Students with Learning Difficulties. The Guilford Press.

Lin, L.-F. (2017). Impacts of the Problem-based Learning Pedagogy on English Learners' Reading Comprehension, Strategy Use, and Active Learning Attitudes. Journal of Education and Training Studies, 5(6), 109. https://doi.org/10.11114/jets.v5i6.2320

Manz, S. . (2002). A Strategy for Previewing Textbooks: Teaching Readers to Become THIEVES Author ( s ): Suzanne Liff Manz Source: The Reading Teacher, Vol. 55 , No . 5 ( Feb., 2002 ), pp . 434-435 Published by: Wiley on behalf of the International Reading Association. 55(5), 434-435.

McDonough, J., Shaw, C. \& M. H. (2013). Materials and Methods in ELT_A Teacher's Guide (3rdEd). West Sussex Wiley-Blackwell, March.

Moreillon, J. (2007). Collaborative strategies for teaching reading comprehension: maximizing your impact.

Novia, N. (2013). Teaching Reading Narrative Text By Using Thieve Strategy. 2129.

Nunan, D. (2015). Teaching English to speakers. Teaching English to Speakers of Other Languages -An Introduction, 210.

Özdemir, E. Ç., \& Akyol, H. (2019). The development of a reading comprehension test. Universal Journal of Educational Research, 7(2), 563 570. https://doi.org/10.13189/ujer.2019.070229

Papatga, E., \& Ersoy, A. (2016). Improving reading comprehension skills through the SCRATCH program. International Electronic Journal of Elementary Education, 9(1), 124-150.

Phillips, D.A. \& Carr, K. (2010). Becoming A Teacher through Action Research. Taylor \& Francis Group. 
Sari, R. M., Yunita, W., \& . A. (2018). Improving Students' Ability To Write Narrative Text By Using Graphic Organizer. JOALL (Journal of Applied Linguistics \& Literature), 1(2), 40-45. https://doi.org/10.33369/joall.v1i2.4179

Sarifuddin and Nunggrasari. (2019). The Effectiveness Of Thieves Strategy Towards Students' Motivation In Reading Comprehension Muhammad. Foresight, 8(5), 55.

http://ejournal.mandalanursa.org/index.php/JUPE/index\%0AVol. Sheng, H. J. (2000). A Cognitive Model for Teaching Reading Comprehension. Forum, 38, 12-15. https://eric.ed.gov/?id=EJ648963 Snow, C. E. (2002). Reading For Understanding: Toward a Research and Development Program in Reading Comprehension. RAND's Publication. Sudijono. (2006). Pengantar Statistik Pendidikan. PT. Raja Grafindo Persada. Tindall, E., \& Nisbet, D. (2010). Exploring the essential components of reading. Jour $n$ nal of Adult Education, 39, 1-9.

\section{THE AUTHORS}

Yenny Asmarni is an English teacher at SMP Negeri 13 Bengkulu Utara, Bengkulu, Indonesia. She earned her master degree in Postgraduate Program of English Education, Universitas Bengkulu in 2020. Her research interest is ELT Methodology and innovation. She can be contacted via yennydaman1@gmail.com.

Wisma Yunita is a senior English lecturer at the Postgraduate Program of English Education, Universitas Bengkulu, Indonesia. She earned her doctoral degree in Language Education from Universitas Negeri Jakarta in 2018. Her research interests are English Grammar, Academic Writing, ELT Methodology and Innovation, and ELT research. She can be contacted via wismayunita@unib.ac.id.

Dedi Sofyan is a lecturer at the English department, University of Bengkulu, focusing on linguistics and education. He has an interest on students' internal factors influencing the successfulness in study. He mostly studied several aspects such as anxiety, motivation, communication strategies, learning strategies and learning style. He also wrote several works on evaluation, test item construction and textbook analysis. 


\section{APPENDIX 1}

Figure 1. Conceptual Framework

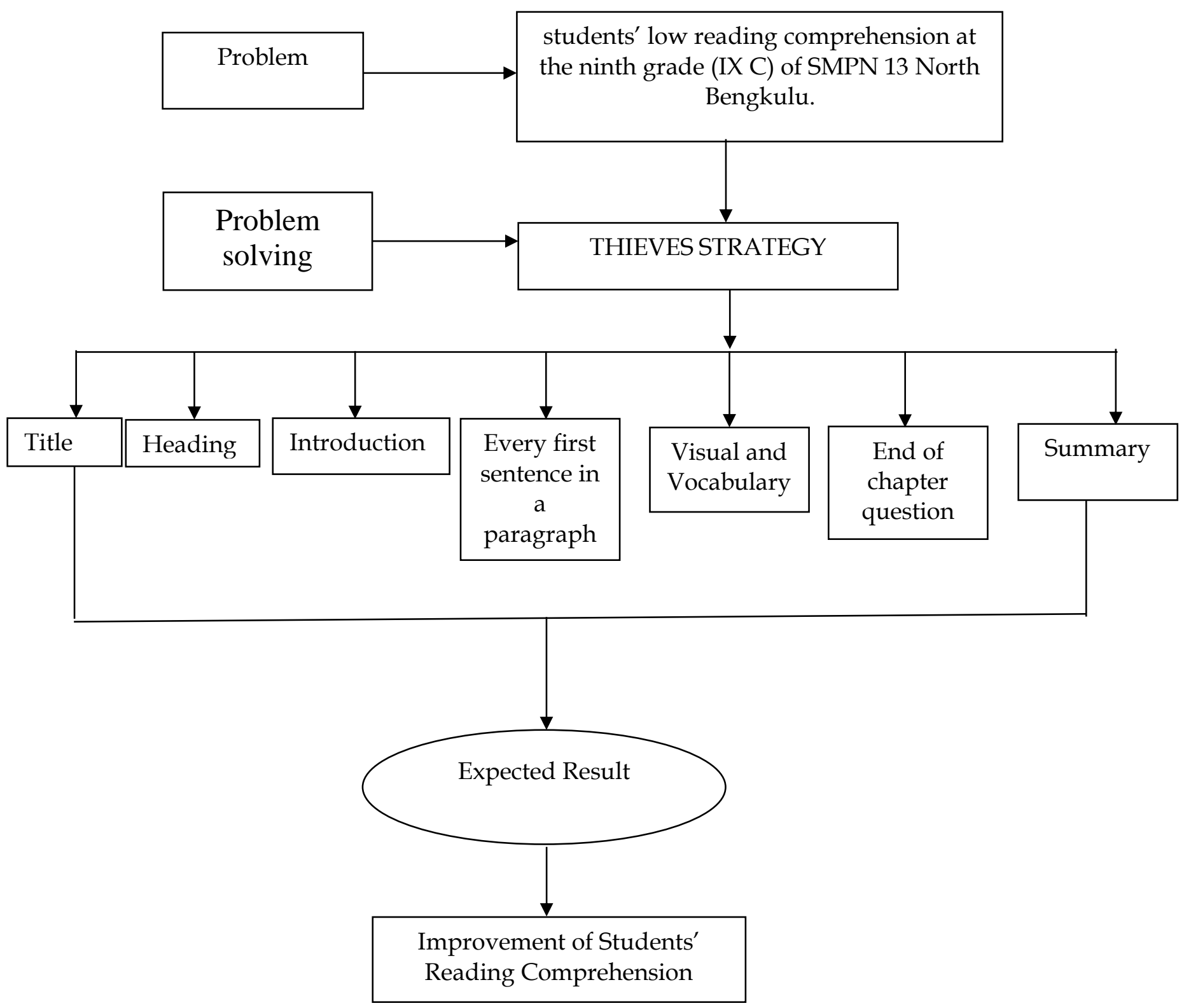




\section{APPENDIX 2}

\section{Reading Comprehension Test I}

The text is for questions number $1-7$

Putri Gading Cempaka

Once, in Bengkulu Tinggi area which is included in Bengkulu Province. There was a kingdom called the Kingdom of Sungai Serut. The King named was Ratu Agung. Ratu Agung had six sons and a daughter. They were named Kelamba Api or Raden Cili, Manuk Mincur, Lemang Batu, Taj Rompong, Rindang Papan, Anak Dalam, and Putri Gading Cempaka.

Suddenly, the king was seriously ill. He Asked Anak Dalam to be a King. He hoped that this kingdom would remain united both in joy and sorrow. When Sungai Serut Kingdom was hit by a big disaster and no longer be maintained, the kingdom had to move to Gunung Bungkuk, then there would come a king who asked Putri Gading Cempaka to be his wife. After the king had sentence the message, he passed away and Anak Dalam crowned to be a king. However, the name of the kingdom changed to Bangkahulu Kingdom by Anak Dalam.

One day, the young Prince of Aceh came to propose the Putri Gading Cempaka, but proposal was refused by all members of king's family. The Pangeran Muda Aceh became angry and declared the Kingdom to fight. War continued to rage and many troops died. At that moment, the King remembered the message of his father. Finally, King Anak Dalam and his six siblings immediately run away and moved to Gunung Bungkuk.

After king and his family left, the Bangkahulu Kingdom became chaotic. The news of the war heard by four pasirah (Knights) of Lebong Balik Bukit and they willing to owned the Bangkahulu Kingdom. However, after they had the entire kingdom they started to fight each other to be the king. All the knights then asked to Baginda Maharaja Sakti to settle off the fight among them. After the fight settled Baginda Maharaja crowned as the new king. However, suddenly the sky went dark, heavy rains and heavy winds fell, the ceremony was finally postponed. However, until evening, rain and storms never stopped. Baginda Maharaja Sakti dreamed of seeing an angel dancing in a rainstorm, but not even a little of the angel's body was wet with rain. The angel then heads to Gunung Bungkuk. The next day, he asked a fortune teller to interpret the dream. The fortune teller said that the beautiful angel was Putri Gading Cempaka, who lived on Gunung Bungkuk with her six siblings. The fortune teller said if the Baginda Maharaja able to marry the princess, the kingdom would be better. Then Baginda Maharaja went to Gunung Bungkuk propose Putri Gading Cempaka.

Finally, Raja Anak Dalam and his brothers accepted the Maharaja Sakti's proposal in based on their father's will. They built a new kingdom called Lemau River Kingdom. His Majesty Sakti led the kingdom wisely. He and his queen also live happily. (Adapted from https://www.bigbanktheories.com/contoh-narrative-text-panjangtentang-putri-gading-cempaka/)

1. How many children did Ratu Agung have?
A. Four
C. Five
B. Six
D. Seven 
2. "He hoped that this kingdom would..." The word 'He' Paragraph 2 line 1 refers to...
A. The king
C. Anak Dalam
B. The Prince
D. Baginda Maharaja Sakti

3. Raja Anak Dalam and his brothers accepted the Maharaja Sakti's proposal... The underlined word of the last paragraph has the same meaning as...
A. Refused
C. Received
B. Remarked
D. Read

4. What is the moral value of the text above?
A. Do anything to get what you want
B. Always remember advice from our parents
C. Everyone have to be a king
D. Every people in the world must live happily.

5. What did Anak Dalam do after all troops died?
A. He accepted Baginda Maharaja Sakti porposal.
B. He and his people fight until died.
C. He and his Family moved away to Gunung Bungkuk.
D. Anak Dalam refused Pangeran Muda Aceh's proposal.

6. What does the text tell us about?
A. Bengkulu province
B. Putri Gading Cempaka
C. Sungai Serut Kingdom
D. Gunung Bungkuk

7. What is the main idea of Paragraph 4 ?

A. Baginda Maharaja asked Fortune teller to inteprete the dream.

B. Baginda Maharaja crowned as the new king.

C. The fortune teller said Baginda Maharaja to marry the princess.

D. Bangkahulu Kingdom became chaotic after the King left.

\section{The following text is for number $8-14$}

Pasar bawah (Down Market) is a must visit location when exploring Riau. It is the market in Pekanbaru located on the riverside of Siak River and the port. The market itself is unique because instead of selling fruit and vegetables, this place sells antique goods and knick-knacks from local areas and overseas.

This market also sells products from Malaysia, Singapore and Italia as well as second-hand electronics in affordable price.

In this market, it can be found local products from Riau such as Riau batik, Riau tenun ( Riau- style Woven fabrics), and Malay traditional clothing. Local food are also avalaible such as lempuk durian (sticky sweet cake made by durian fruit), dodol kedondong ( kedondong glutinous sweet), ikan salai (smoked fish) and ikan asin (salted fish).

(taken from https://www.thejakartapost.com/travel/2017/07/08/findantique-goods-at-pekanbarus-oldest-market-pasar-bawah.html

8. What is the text about? 

A. The beauty of Siak River in Riau
B. Batik Riau cloth avalaible at the market
C. A market named Pasar Bawah
D. History of Siak Port near Pasar Bawah

9. "It is the market..." Paragraph 1 line 1. The word it refers to...
A. Pekan Baru
C. Malaysia
B. Pasar Bawah
D. Riau Tenun

10. Where is Pasar Bawah located?
A. On the riverside of Siak River and the port.
B. On the riverside of Musi River and the port.
C. In Malysia
D. In Italy

11. Which statement is incorrect based on the text?
A. The Market sells fruits and vegetables.
B. The market sells antique goods and knick - knacks.
C. Malay traditional clothing is available in the market.
D. Location of Siak River is near the market.

12. What is the main idea of third paragraph?
A. The history of Pasar Bawah.
B. Local products and food sold in Pasar Bawah.
C. Special sticky sweet cake Pasar Bawah.
D. Smoked fish and salted fish in Pasar Bawah.

13. "...... this place sells antique goods and knick-knacks..." (Paragraph 1) The underlined word can be replaced by...
A. Vintage
C. Modern
B. New
D. Sophisticated

14. Where does the second-hand electronics come from?
A. Tiongkok, Italy, and Malaysia
B. Malaysia, Italy, and Philipines
C. Malaysia, Italy, and Singapore
D. Singapore, Italy, and Philipines

The text is for number $15-20$

Snakes are reptiles (cold-blooded creatures). They belong to the same group as lizards (the scaled group, Squamata) but from a sub-group of their own (Serpentes).

Snakes have two legs but a long time ago they had claws to help them slither along. Snakes are not slimy. They are covered in scales which are just bumps on the skin. Their skin is hard and glossy to reduce friction as the snake slithers along the ground.

Snakes often sun bathe on rocks in the warm weather. This is because snakes are cold-blooded; they need the sun's warmth to heat their bodies up. 
Most snakes live in the country. Some types of snakes live in tress, some live in water, but most live on the ground in deserted rabbit burrows, in thick, long grass and in old logs.

A snake's diet usually consists of frogs, lizard, and mice and other snakes. The Anaconda can eat small crocodiles and even bears. Many snakes protect themselves with their fangs. Some snakes are protected by scaring their enemies away like the Cobra. The flying snakes glide away from danger. Their ribs spread apart and the skin stretches out. Its technique is just like the sugar gliders.

15. Based on the information of the text, we know that snakes...
A. Do not have claws.
B. Do not like sunlight.
C. Have two legs and claws
D. Use their claws to slither along the ground

16. Since the snakes are cold-blooded, they ...
A. Require the sun's warmth to heat their body.
B. Like sucking the cool blood.
C. Never sun bathe in the warm weather.
D. Live on the ground in deserted burrows.

17. Some types of snakes live in tress, some live in water, but most live on the ground in deserted rabbit burrows,...(paragraph 4). The word "burrows " has the similar meaning with...
A. Foster
C. Dig
B. Plough
D. Nurture

18. How do flying snakes protect themselves?
A. They fly away.
B. They use their fanngs they scare their enemies.
C. They stretch out their skin.
D. They eat the other animals.

19. "They belong to..." The word 'they' in Paragraph 1 line 1 refers to...
A. Anacondas
C. Claws
B. Snakes
D. Rabbits

20. What is the purpose of the text?
A. To amuse the reader about snakes
B. Presenting information about snakes.
C. Telling the procedure of keeping the snakes
D. Telling about past event. 
APPENDIX 3

Table 1. The Observation List for teacher Cycle I Meeting I

\begin{tabular}{|c|c|c|c|}
\hline Aspect & Indicator & Yes & No \\
\hline Pre- Activity & $\begin{array}{l}\text { - Teacher asks the leader to lead the pray. } \\
\text { - Teacher asks questions about the material. } \\
\text { - Teacher tells the students about the aim of the } \\
\text { lesson. } \\
\text { - Teacher tells the student about some } \\
\text { assessments while the learning process. }\end{array}$ & $\begin{array}{l}\checkmark \\
\checkmark \\
\checkmark\end{array}$ & \\
\hline Title & $\begin{array}{l}\text { - Teacher asks the students whether they have } \\
\text { already known about the title. } \\
\text { - Teacher asks how this chapter will relate to } \\
\text { chapters students have already read. } \\
\text { - Teacher asks the students What they predict } \\
\text { will be in this chapter. }\end{array}$ & $\begin{array}{l}\checkmark \\
\checkmark \\
\checkmark\end{array}$ & \\
\hline Headings & $\begin{array}{l}\text { - Teacher asks the students based on the } \\
\text { headings, what information will each section } \\
\text { contain? } \\
\text { - Teacher asks the students which sections look } \\
\text { most important? } \\
\text { - Teacher asks the students how can you turn } \\
\text { these headings into guiding questions? }\end{array}$ & $\begin{array}{l}\checkmark \\
\checkmark\end{array}$ & \\
\hline Introduction & $\begin{array}{l}\text { - Teacher asks the students where is the } \\
\text { introduction? How can you tell? } \\
\text { - Teacher asks the students what are the main } \\
\text { ideas of the introduction? } \\
\text { - Teacher asks the students what information } \\
\text { do you already know about this topic? }\end{array}$ & $\begin{array}{l} \\
\checkmark\end{array}$ & \\
\hline $\begin{array}{l}\text { Every first } \\
\text { paragraph } \\
\text { sentence }\end{array}$ & $\begin{array}{l}\text { - Teacher asks the students what are some of } \\
\text { the topics that will be included? } \\
\text { - Teacher asks the students which topics, and } \\
\text { which paragraphs, are most important? } \\
\text { - Teacher asks the students what do you think } \\
\text { you will learn about? }\end{array}$ & $\begin{array}{l}\checkmark \\
\checkmark \\
\checkmark\end{array}$ & \\
\hline $\begin{array}{ll}\text { Visuals } & \text { and } \\
\text { vocabulary } & \end{array}$ & $\begin{array}{l}\text { - Teacher asks the students what can each } \\
\text { visual tell you? What's its main message? } \\
\text { Teacher asks the students based on the } \\
\text { visuals, what do you predict you will read } \\
\text { about? } \\
\text { - Teacher asks the students based on the } \\
\text { words, what do you think you will learn? }\end{array}$ & $\begin{array}{l}\checkmark \\
\checkmark\end{array}$ & \\
\hline $\begin{array}{l}\text { End of chapter } \\
\text { questions }\end{array}$ & $\begin{array}{l}\text { - Teacher asks the students based on these } \\
\text { questions, what do you think will be some of } \\
\text { the main ideas of this chapter? }\end{array}$ & $\checkmark$ & \\
\hline
\end{tabular}




\begin{tabular}{|l|l|c|c|}
\hline \multicolumn{1}{|c|}{ Aspect } & \multicolumn{1}{|c|}{ Indicator } & Yes & No \\
\hline Summary & $\begin{array}{l}\text { Teacher asks the students based on these } \\
\text { questions, what predictions can you make } \\
\text { about the chapter? }\end{array}$ & & \\
\hline $\begin{array}{l}\text { Teacher asks the students what does it seem } \\
\text { like the main ideas of this chapter are? } \\
\text { Teacher asks the students what material is } \\
\text { going to be covered? } \\
\text { Teacher asks the students what do you } \\
\text { already understand from this summary? }\end{array}$ & $\checkmark$ & $\checkmark$ & \\
\hline Post - Activity & $\begin{array}{l}\text { Teacher and the students make a summary } \\
\text { about the topic that have been learnt together. } \\
\text { Teacher do some reflection to activities that } \\
\text { have been done. } \\
\text { Teacher asks whether the students still have } \\
\text { some questions } \\
\text { Teacher close the activity by thanking and } \\
\text { greeting }\end{array}$ & $\checkmark$ & $\checkmark$ \\
& & $\checkmark$ & \\
\hline
\end{tabular}

Table 2. The Observation List for Students Cycle I Meeting I

\begin{tabular}{|c|c|c|c|}
\hline Aspect & Indicator & Yes & No \\
\hline Pre- Activity & $\begin{array}{l}\text { - The leader of the students leads the pray. } \\
\text { - Students answer questions about the } \\
\text { material. } \\
\text { - The students listen to the aim of the lesson. } \\
\text { - Teacher tells the student about some } \\
\text { assessments while the learning process. }\end{array}$ & $\begin{array}{l}\checkmark \\
\checkmark \\
\checkmark \\
\checkmark\end{array}$ & \\
\hline Title & $\begin{array}{l}\text { - The students answer whether they have } \\
\text { already known about the title. } \\
\text { - The students answer how this chapter will } \\
\text { relate to chapters students have already } \\
\text { read. } \\
\text { - The students answer what they predict will } \\
\text { be in this chapter. }\end{array}$ & $\checkmark$ & $\checkmark$ \\
\hline Headings & $\begin{array}{l}\text { - Based on the headings the students answer, } \\
\text { what information will each section contain? } \\
\text { - The students answer which sections look } \\
\text { most important? } \\
\text { the students answer how can they turn } \\
\text { these headings into guiding questions? }\end{array}$ & $\checkmark$ & $\begin{array}{l}\checkmark \\
\checkmark\end{array}$ \\
\hline
\end{tabular}




\begin{tabular}{|c|c|c|c|}
\hline Aspect & Indicator & Yes & No \\
\hline Introduction & $\begin{array}{l}\text { - The students answer where is the } \\
\text { introduction? How can they tell? } \\
\text { - The students answer what are the main } \\
\text { ideas of the introduction? } \\
\text { - The students answer what information do } \\
\text { they already know about this topic? }\end{array}$ & $\checkmark$ & $\begin{array}{l}\checkmark \\
\checkmark\end{array}$ \\
\hline $\begin{array}{ll}\text { Every } & \text { first } \\
\text { paragraph } & \\
\text { sentence } & \end{array}$ & $\begin{array}{l}\text { - The students answer what are some of the } \\
\text { topics that will be included? } \\
\text { - The students answer which topics, and } \\
\text { which paragraphs, are most important? } \\
\text { - The students answer what do they think } \\
\text { they will learn about? }\end{array}$ & & $\begin{array}{l}\checkmark \\
\checkmark \\
\checkmark\end{array}$ \\
\hline $\begin{array}{ll}\text { Visuals } & \text { and } \\
\text { vocabulary } & \end{array}$ & $\begin{array}{l}\text { - The students answer what can each visual } \\
\text { tell they? What's its main message? } \\
\text { - The students answer based on the visuals, } \\
\text { what do they predict you will read about? } \\
\text { - The students answer based on the words, } \\
\text { what do they think they will learn? }\end{array}$ & & $\begin{array}{l}\checkmark \\
\checkmark \\
\checkmark\end{array}$ \\
\hline $\begin{array}{l}\text { End of chapter } \\
\text { questions }\end{array}$ & $\begin{array}{l}\text { - The students answer based on these } \\
\text { questions, what do they think will be some } \\
\text { of the main ideas of this chapter? } \\
\text { - The students answer based on these } \\
\text { questions, what predictions can they make } \\
\text { about the chapter? }\end{array}$ & & $\begin{array}{l}\checkmark \\
\checkmark\end{array}$ \\
\hline Summary & $\begin{array}{l}\text { - The students answer what does it seem like } \\
\text { the main ideas of this chapter are? } \\
\text { - The students answer what material is going } \\
\text { to be covered? } \\
\text { - The students answer what do you already } \\
\text { understand from this summary? }\end{array}$ & & $\begin{array}{l}\checkmark \\
\checkmark \\
\checkmark\end{array}$ \\
\hline Post - Activity & $\begin{array}{l}\text { - The students make a summary about the } \\
\text { topic that have been learnt together. } \\
\text { - Teacher do some reflection to activities that } \\
\text { have been done. } \\
\text { - Teacher asks whether the students still have } \\
\text { some questions } \\
\text { - Teacher close the activity by thanking and } \\
\text { greeting }\end{array}$ & $\checkmark$ & $\begin{array}{l}\checkmark \\
\checkmark \\
\checkmark\end{array}$ \\
\hline
\end{tabular}




\section{APPENDIX 4}

Table 3. Field Notes for Teacher and students

\begin{tabular}{|c|c|l|}
\hline No & Cycle & \multicolumn{1}{c|}{ Field notes } \\
\hline 1 & I & $\begin{array}{l}\text { In the first meeting, the teacher began the learning process and } \\
\text { managed the classroom well. She just told about main idea without } \\
\text { asking the information the students had got from the text. She had } \\
\text { given the explanation about each step but the students were still very } \\
\text { confusing about the steps of the strategy. There still some students } \\
\text { who did chatting among the students which were in the different } \\
\text { group. At the end of the meeting she tried to summarize what the } \\
\text { students got at this meeting then closed the meeting well. At the } \\
\text { second meeting, the teacher began the meeting well. She managed } \\
\text { the classroom well and effective. She gave the explanation about the } \\
\text { strategy, step by step, little by little. So that the students were not so } \\
\text { confused about the strategy and start to be more enthusiasm in doing } \\
\text { their task. Finally, the teacher closed the meeting very well. In the } \\
\text { third meeting, the teacher had given the explanation clearly. Almost } \\
\text { all steps were done well by the teacher. }\end{array}$ \\
\hline 2 & II & $\begin{array}{l}\text { In the first meeting of cycle II, the teacher began the learning process } \\
\text { very well. She gave the explanation about THIEVES strategy and } \\
\text { what the students should do in this meeting clearly. The students had } \\
\text { understood enough about the steps of THIEVES strategy. Only two } \\
\text { or three students who asked about the steps. They still found some } \\
\text { difficulties in step Every first paragraph. Then, in the second meeting } \\
\text { after opening the class and giving the explanation about what should } \\
\text { the students do, the teacher come to each group to ask whether they } \\
\text { found some difficulties in applying THIEVES strategy to } \\
\text { comprehend the text they had. The students showed a very good } \\
\text { respond. They looked very happy and enthusiasm to do their task by } \\
\text { applying the strategy. }\end{array}$ \\
\hline
\end{tabular}




\section{APPENDIX 5}

\section{Transcript of the Interview}

$\begin{array}{ll}\text { Day/Date } & : \text { Monday/March, } 16^{\text {th }} 2020 \\ \text { Place } & : \text { Teacher's room } \\ \text { Time } & : 09.30-10.00 \\ \text { Interviewees } & : \text { Student } 17, \text { Student } 19, \text { Student } 25\end{array}$

1. Researcher : Ee... Oke.. kira - kira dalam...apa,.. memahami teks itu yang jadi problemnya apa ..yang jadi..yang jadi kendala selama ini apa ?

Student 19 : Kadang ... saya bingung, Mam. Mau mulai darimana, apalagi kalau banyak kata - kata barunya, Mam...

2. Researcher : Oke... aa..kita kan udah nerapkan, sekarang ada strategi baru, kira - kira ee...perbandingannya gimana itu? Perbedaannya gimana? Antara dulu sebelum ada strategi yang kita pake dalam pembelajaran kemudian sekarang ada strategi yang kita pake THIEVES strategi ee... gimana .. gimana..ee pendapatnya gimana?

Student 25 : Kalau sebelum ada strateginya tu kan, Mam. Kalau belajar yang ada teks kurang menarik, tapi sekarang karena ada strategi yang menuntun kita.. mmm dengan langkah - langkah yang jelas jadi lebih mudah ngerjainya.

3. Researcher : Oke..ee...kemaren kan kita udah nerapkan strategi itu kan. Strategi tentang memahami teks, THIEVES strategy. Eee.. kira - kira bagaimana perasaan kamu setelah eee.. menerapkan strategi ini dalam, apa.. mem..ee.. mempelajari teks... dalam memahami teks gitu... gimana perasaannya?

Student 17 : Kalau sebelumnya kan Mam, kalau lihat teks, apalagi kalau teksnya panjang. Saya langsung putus asa aja mam, dan kurang semangat mau tau tentang teksnya. Tapi pas dikenalin strategi ini, jadi penasaran pengen tau dan semangat buat tau, dengan menerapkan urutan dalam strateginya, Mam. Mmm mulai dari judulnya...sampai menyimpulkan isi teksnya. Dari strategi ini, saya akan memprediksikan pertanyaan apa yang akan muncul dari teks dan jawabannya.

Researcher : Oke...Thank you. 